Article

\title{
Blockchain Technology Adoption Behavior and Sustainability of the Business in Tourism and Hospitality SMEs: An Empirical Study
}

\author{
Guych Nuryyev ${ }^{1}$, Yu-Ping Wang ${ }^{2}$, Jennet Achyldurdyyeva ${ }^{2, *}$, Bih-Shiaw Jaw ${ }^{2}$, Yi-Shien Yeh ${ }^{2}$, \\ Hsien-Tang $\mathrm{Lin}^{2}$ and Li-Fan $\mathrm{Wu}^{2}$ \\ 1 International Finance Department, I-Shou University, Kaohsiung 84001, Taiwan; gnuriyev@isu.edu.tw \\ 2 Institute of Human Resource Management, National Sun Yat-Sen University, Kaohsiung 80424, Taiwan; \\ cwang@mail.nsysu.edu.tw (Y.-P.W.); bsjaw510@mail.nsysu.edu.tw (B.-S.J.); \\ d034050002@student.nsysu.edu.tw (Y.-S.Y.); st_lin@aseglobal.com (H.-T.L.); \\ d024050001@student.nsysu.edu.tw (L.-F.W.) \\ * Correspondence: d024050005@student.nsysu.edu.tw
}

Received: 9 December 2019; Accepted: 25 January 2020; Published: 10 February 2020

\begin{abstract}
This paper investigates the factors influencing the intention to adopt cryptocurrency payments among small to medium-sized enterprises (SMEs) in tourism and hospitality through the lens of the technology acceptance model (TAM). This paper uses an original sample of 101 SMEs employing a total of 15,831 people in Taiwan. Structural equation modeling is used to examine the joint effect of both internal and external factors influencing the intention to use cryptocurrency payments. Results show that (1) strategic orientation, owner/managers personal characteristics (self-efficacy and innovativeness) and social influence have a strong effect on the intention to adopt new technology; (2) perceived usefulness mediates the effects of strategic orientation and social influence; and (3) perceived ease of use mediates the effect of self-efficacy on the intention to adopt cryptocurrency payments. The present study is one of few empirical inquiries about cryptocurrency payment adoption among SMEs. This study extends the theoretical foundations of the TAM into the specific characteristics of SMEs. Limitations of the study are sample size and a single survey design. However, findings of this research on the cryptocurrency payment adoption offer practical implications for tourism stakeholders towards supporting SMEs competitiveness. The originality of this study is based on the fact that cryptocurrency payment is a new technology, and on the potential of cryptocurrency payments to disrupt the traditional way of operating tourism and hospitality SMEs. Hence the importance to consider major factors influencing SMEs' intentions to adopt this technology.
\end{abstract}

Keywords: hospitality; tourism; operations management; technology acceptance model; technology adoption behavior; blockchain; small and medium enterprises

\section{Introduction}

Information technology (IT) is a strategic asset for organizational performance and competitiveness in the tourism and hospitality industry [1] and for small and medium enterprises (SMEs) [2,3]. IT adoption in this study is defined as a process of accepting and implementing IT to deliver services such as booking, reservation and payment. SMEs comprise the majority of businesses in many regions of the world $[4,5]$ and are crucially important for many economies [6-8]. There is a gap in our understanding of the behavior of tourism and hospitality SMEs in IT adoption in general [9-12] and in blockchain technology adoption in particular [13].

Tourism and hospitality SMEs operate in a challenging business environment and face intense competition from traditional (e.g., established hotel chains, such as the Hilton, Marriot and Sheraton) and 
new players (e.g., Airbnb) in the industry [14,15]; and ever increasing demands from customers [16-18]. In this environment, business sustainability becomes an important issue. Sustainable tourism is defined as 'tourism that takes full account of its current and future economic, social and environmental impacts, addressing the needs of visitors, the industry, the environment and host communities' [19-21]. The present study focuses on the tourism and hospitality SMEs business sustainability due to their economic impact in relation to host communities. SMEs depend on their ability to adapt to new technological trends in order to sustain competitiveness [22]. Due to the central role of IT for SMEs business performance and the importance of tourism and hospitality SMEs for economic development [23] it is important to understand more about their IT adoption behavior [9,12].

Blockchain technology and cryptocurrency payments are widely recognized as a pioneering technological innovation [24] that can disrupt the way traditional tourism and hospitality businesses operate $[13,25]$. While there are studies looking into the implications of blockchain technology in tourism management and marketing [25-28], there is not sufficient empirical enquiry into cryptocurrency payment, which could become a mainstream payment method in the future $[29,30]$. Cryptocurrency is a digitally distributed currency, independent of any particular geographic location or government regulations [31]. Cryptocurrency transactions are irreversible, pseudo anonymous, and public: no payer or receiver are identified by name, but transactions are visible on a peer-to-peer network [32]. The growing popularity of cryptocurrency payments is due to widespread interest among the millennial generation in this new way of transacting without third party mediation $[24,33]$.

Due to the rapid growth of blockchain technology and cryptocurrency payments, it is necessary to identify factors that affect both the perceived ease of use and the perceived usefulness of cryptocurrency payment. The present study adapts the technology acceptance model (TAM) [34], in order to study these factors $[30,35,36]$. Previous studies of factors influencing SMEs' IT adoption behavior have identified such factors as top management innovativeness [37] and perceived behavioral control [38]; strategic context [39-41]; family members in management [39,42,43]; limitations in education and training, and lack of strategic planning, financial resources, management and marketing abilities [44]; and a highly centralized structures where owner and manager are the same person [45]. However, the paucity of studies about the joint effect of internal and external factors influencing SMEs' IT adoption behavior was repeatedly noted [46-49]. Additionally, previous multi-industry studies of SMEs' IT adoption behavior did not take into account specific industry characteristics [50-52], leading to contradictory findings [10]. Therefore, this research provides an empirical investigation into the factors affecting tourism and hospitality SMEs' intention to adopt cryptocurrency payments. Location and data collection of the study were chosen due to cryptocurrency-friendly legal and supporting technological infrastructure (e.g., quality of Wi-Fi connectivity in hotels and restaurants) which enable blockchain technology adoption and allow to conduct an empirical investigation in relevant settings [13].

This paper extends the scope of research on tourism and hospitality SMEs' IT adoption by empirical examination of both the internal and the external factors affecting the adoption behavior. Secondly, this paper extends the theoretical foundations of the TAM into the specific characteristics of SMEs in tourism and hospitality [12]. Finally, this study adds to the understanding of the under-researched phenomenon of blockchain, specifically cryptocurrency payment integration into tourism and hospitality operations and management $[13,25]$.

The paper is organized as follows: based on the literature review, the authors first formulate a set of hypotheses about IT adoption behavior among tourism and hospitality SMEs. The next section of the paper discusses the methodology: sample and data, variables and measures. The results are then presented to show the factors affecting the IT adoption behavior of SMEs. The final section discusses the contributions to theory and practice and the limitations of the study. 


\section{Literature Review}

\subsection{Predicting Technology Adoption}

Well-established theoretical frameworks about IT adoption behavior include the theory of reason action [53], theory of planned behavior [54], technology acceptance model (TAM) [34], TAM 2 [55], TAM 3 [56] and the unified theory of acceptance and use of technology (UTAUT) [57]. Rad's 2018 comprehensive review examining the trend of technology adoption research stated that the TAM is the most dominant of the theories [30]. TAM's influence is explained by its simplicity and validity in terms of theoretical attributes, empirical foundation and general applicability to technology adoption issues in diverse domains. TAM allows estimating IT adoption based on usage measures, objectively and subjectively [58]. TAM also allows focusing on social and individual factors [59], which are considered in this study.

The theoretical assumption in the TAM framework is that the behavioral intention (BI) to adopt new IT is determined by two main factors: perceived usefulness (PU) and perceived ease of use (PEOU). PU is the extent to which a person believes that using an IT will enhance performance, and PEOU is the degree to which a person believes that using an IT will be free of effort $[34,55,57]$. PE and PEOU have direct impact on IT adoption [30,60,61]. Additionally, it is theorized and tested empirically that PEOU operates indirectly through PU [34,62-64]. The present study examines the relationships between PU and PEOU and their influence on the intention to adopt cryptocurrency payment in order to replicate the existing theory in the novel context of blockchain technology. The following hypotheses are proposed:

Hypothesis 1. PU of cryptocurrency payment positively affects $S M E s^{\prime} B I$.

Hypothesis 2. PEOU of cryptocurrency payment positively affects SMEs' BI.

Hypothesis 3. There is a positive relationship between the PEOU of cryptocurrency payment and PU of its adoption.

Previous studies have predominantly analyzed internal factors and external factors separately. The following constructs influence technology acceptance: individual differences [55,65-69], new technology characteristics $[34,70,71]$, social influences [55,56,71-74] and organizational characteristics [70]. Identification of both internal and external factors is relatively scarce in IT innovation literature [46].

Wang and Qualls [12] adapted TAM and proposed an integrated model of IT adoption behavior in tourism and hospitality organizations with consideration of both internal and external factors. Their model focuses on such internal antecedents of adoption as strategic orientation, organization technology climate, technology characteristics, information processing characteristics and external factors-supplier marketing strategies [12]. They also mentioned that SMEs' owner/manager individual characteristics have to be taken into consideration, as the owner/manager's technology expertise makes a positive impact on adoption [75].

This study draws from the models of TAM [12] and integrates two additional important antecedents of IT adoption in SMEs: owner/manager individual characteristics [76] and social influence [77,78]. Figure 1 illustrates the research model. This study empirically examines the joint effect of such internal factors as strategic orientation and owner/manager individual characteristics, and external factors-social influence and technology characteristics influencing IT adoption behavior among SMEs in tourism and hospitality. The details of these constructs are discussed below. 


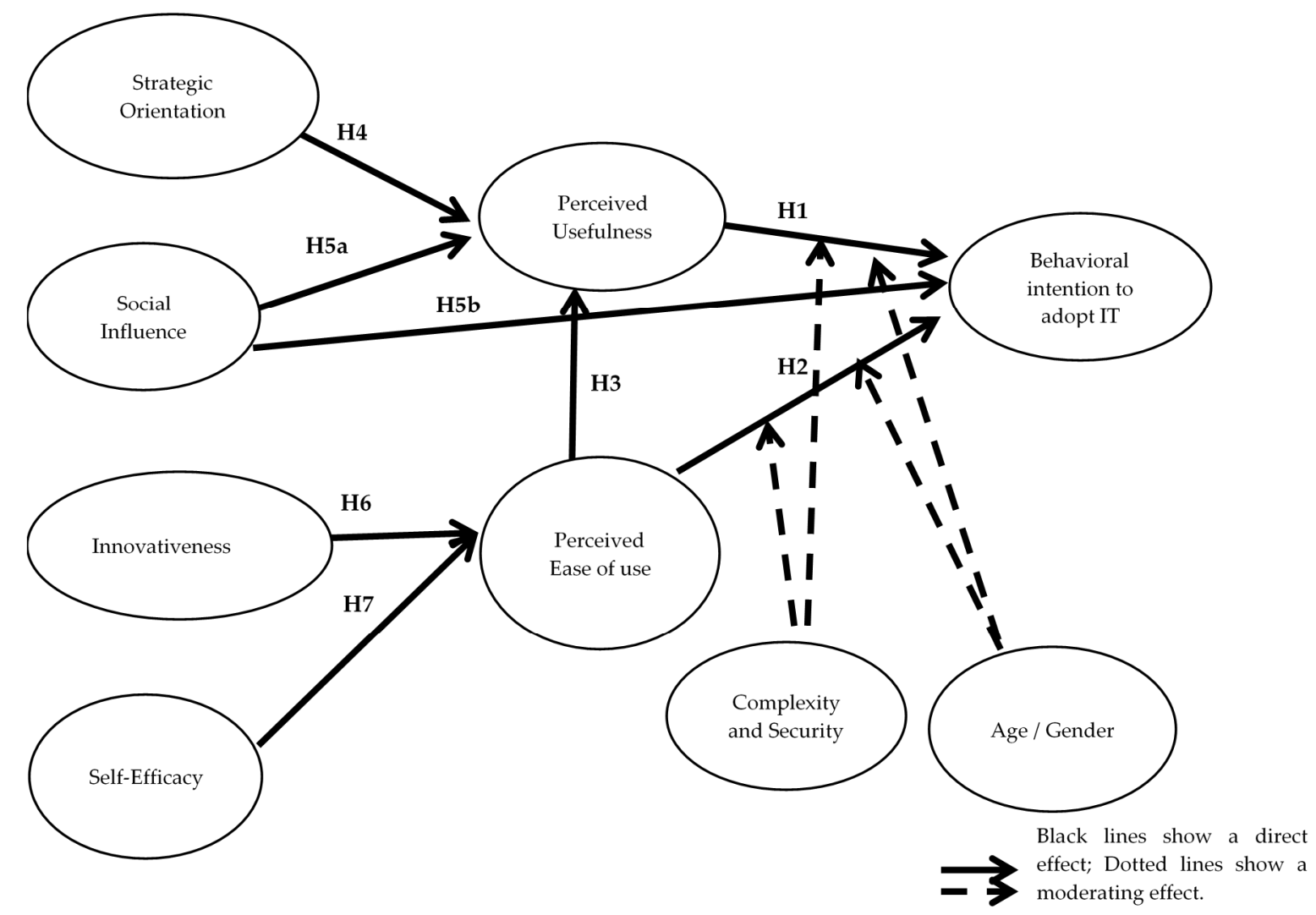

Figure 1. Research model of IT adoption behavior in tourism and hospitality small and medium enterprises (SMEs) adapted from Wang \& Qualls, 2007; Fred Davis, 1989; Venkatesh, Morris, Davis and Davis, 2003.

\subsection{Strategic Orientation}

Strategic orientation is defined as strategic directions taken by the organization in order to create a supportive infrastructure and behavior for business competitiveness [79]. It is also the mechanism for identifying and responding to a competitive environment [12]. Previous research noted that SMEs' strategic orientation is an important factor for IT adoption behavior [39-41,80]. There are three parts of strategic orientation important for tourism and hospitality: customer, competitor and technology $[12,14,18]$.

Customer orientation is defined as "the set of beliefs that put the customer interest first [81] and a firm's understanding of its target customers that allows creating superior customer value" [79]. Wang and Qualls [12] hypothesize that if a customer-oriented hospitality organization decides that using technology can improve customer service, it will be more likely to adopt the technology.

Competitor orientation is defined as the ability to identify, analyze and respond to competitors' behavior in the marketplace [79]. Competitor-oriented tourism and hospitality organizations are hypothesized to not hesitate to adopt new IT if their competitors are utilizing those IT for a competitive advantage [12].

Technological orientation is defined as the ability of a firm to obtain the necessary IT background and use IT in the development of new products and services [12]. Technological-oriented hospitality organizations are described as research-oriented and proactive in acquiring new IT [82,83].

From the above it follows that SMEs' strategic orientation positively influences PU. SMEs operating in highly competitive and innovative industries, like tourism and hospitality, are more likely to be driven toward IT adoption than those in other less intensive types of industries, such as agriculture, construction etc. $[76,84,85]$. Hence the present study hypothesizes: 
Hypothesis 4. There is a positive relationship between SMEs' strategic orientation and their PU of cryptocurrency payment.

\subsection{Social Influence}

Social influence is the extent to which individuals perceive that important others (e.g., family and friends) believe they should use a particular technology [77]. It reflects the extent to which an individual places importance on the views of others versus their own view of IT use [86]. It is well established that social influence shapes IT adoption behavior and in turn affects IT use [86-89]. Social influence has a stronger impact on the behavioral intention to use new payment technology than convenience, usefulness and fun [90]. Peer-to-peer communication and social norms are important antecedents of IT adoption [78]. Consequently, a SME's owner/manager's social circle might influence their perceptions about the usefulness of IT and its adoption. Social influence has an indirect effect via PU on BI [91,92] and is moderated by gender, age, experience and voluntariness [57,93]. Following the above, a positive relationship between social influence and SMEs IT adoption behavior is expected.

Hypothesis 5a. There is a positive relationship between social influence and the PU of cryptocurrency payment adoption.

Hypothesis $\mathbf{5 b}$. There is a positive relationship between social influence and the SMEs' BI to adopt cryptocurrency payment.

\subsection{SMEs Owner/Manager's Individual Characteristics}

Individual differences are important factors in the IT adoption process $[56,65,67]$. Individual differences influence perceptions of PU and PEOU and are reflected in personality or demographic variables [56]. Individual differences [62,94] are directly linked to SMEs' owner/manager characteristics [95] as he/she performs daily functions and investment decisions, including IT adoption decisions [42,43,76]. SMEs' owner/manager's [96] cognitive, affective and behavior characteristics were reported to influence IT adoption behavior [97,98]. Particularly SMEs' owner/manager's innovativeness and self-efficacy are expected to influence the behavioral intention to adopt new IT [37,38,76,99,100].

Innovativeness is an individual characteristic that predisposes individuals to try out new IT [62,101] and plays a positive role on IT adoption behavior [62,102]. Innovativeness is a reliable predictor of individuals' attitude, PU, PEOU [103] and IT acceptance [67]. We expected that the innovativeness of SMEs' owner/manager plays a major role in the behavioral intention to adopt cryptocurrency payment technology. It is expected that innovativeness has a positive effect on PEOU and as a result influences the intention to adopt cryptocurrency payments. Hence this study hypothesizes the following:

Hypothesis 6. The SMEs owner/manager innovativeness has a positive effect on the PEOU of cryptocurrency payment.

Self-efficacy is defined as an individual's beliefs regarding his/her ability to use IT [56] or as "judgment of one's ability to use a technology to accomplish a particular job or task" [104,105]. Self-efficacy is positively correlated with IT acceptance and adoption [106-109] including among SMEs [110]. Self-efficacy has a strong influence on PEOU [55] and IT adoption [34,106,111]. Hence this study hypothesizes the following:

Hypothesis 7. The SMEs' owner/manager's self-efficacy has a positive impact on PEOU and behavioral intention to adopt cryptocurrency payments. 


\subsection{IT Characteristics and Cryptocurrency Payments}

IT characteristics are the features that help an individual or organization to develop perceptions regarding PU or PEOU [12,56]. Technology characteristics directly affect both PEOU and PU of IT [34]. The literature on blockchain and cryptocurrency payments states that important characteristics are security (e.g., viability, security risk, third party service failure risk, risk of user error, risk of privacy loss, risk of counterparty fraud, risk of illicit association) and convenience (e.g., free participation, instant transfers, simple interface, control of one's own money, disintermediation, high speed of transfer, low cost of transfer, high transaction security, limited supply, international scope, lowers merchants cost, increase customer trust requirements, higher price volatility) $[13,25,31,33,112,113]$.

In this study we define security as the degree to which users believe in the security of IT [59]. On the one hand, cryptocurrency payments have been negatively associated with illicit dark web commerce $[114,115]$, and on the other hand, every cryptocurrency transaction is recorded on the publicly viewable blockchain, which is designed to increase security $[31,116,117]$. Convenience is related to time and place utility for users $[62,118]$ as IT is intended to make peoples' life easier and simplify everyday tasks [119]. Convenience is one of the most important factors in the success of such IT as mobile commerce [120]. Convenience is also one of characteristics of cryptocurrency payments.

In the context of SMEs in tourism and hospitality, researchers argue that IT characteristics tend to exert a moderating effect on the relationship between the perception of technology and the ultimate adoption behavior $[12,121]$. Following the above we take into consideration the moderating effect of security and convenience of cryptocurrency payments on the effect of PU and PEOU on BI. Additionally, this study considers SMEs' owners/managers' age and gender, which are a moderating construct in the TAM $[55,57]$.

\section{Methodology}

\subsection{Sample and Data}

The original data were collected through a survey carried out among tourism and hospitality SMEs owners/managers in the Hualien area in Taiwan. SMEs owners/managers were contacted through the Hualien County homestay association, which has a database that includes information about more than 200 firms. A total of 150 firms from the association met the requirements of our sample. Firms were selected in line with the adopted definition of SMEs with fewer than 250 employees $[95,122]$. The survey was conducted during the annual association gathering among the owners/managers of hotels, motels, resorts, bed and breakfast and restaurants in the Hualien area in Taiwan in May-June 2018. The questionnaire explored a range of factors related to SMEs' IT adoption behavior. During data collection, each SME owner/manager was approached face to face and was verbally asked whether he/she has knowledge or experience regarding cryptocurrency payments. Respondents who were unaware of cryptocurrency payments were not invited to take part in this survey. The questionnaire also contained two questions on knowledge/usage of cryptocurrency payments ("how would you qualify your level of your knowledge of CC payment?" (1-very low and 5-very high) and "how many times did you make CC payments?" (1-never and 5-several times or more). Following this process the authors received replies from 106 owners/managers, and after reviewing each of the responses, 5 responses were removed, as some questions had not been completed. Therefore, a total of 101 valid questionnaires was collected (response rate of $67.3 \%$ percent) from family owned and non-family owned SMEs. The sample size recommended by the previous research ranges from 30 to 460 cases [123]. Hence the sample size of this study is meaningful for analyzing the constructs and research model. Table 1 shows the demographic profile of respondents and the average age of the SMEs. 


\subsection{Demographics}

Table 1. Demographic profile of respondents.

\begin{tabular}{ccc}
\hline Demographics & Frequency & Percentage \\
\hline Gender & & \\
\hline Male & 39 & $38.6 \%$ \\
Female & 62 & $61.4 \%$ \\
\hline Age & & \\
\hline Under 20 & 1 & $1.0 \%$ \\
$20-29$ & 28 & $27.7 \%$ \\
$30-39$ & 21 & $20.8 \%$ \\
$40-49$ & 19 & $18.8 \%$ \\
$50-59$ & 26 & $25.7 \%$ \\
60 and above & 6 & $5.9 \%$ \\
\hline Education level & & $7.9 \%$ \\
High school & 8 & $63.4 \%$ \\
Bachelor's degree & 64 & $26.7 \%$ \\
Master's degree & 27 & $2.0 \%$ \\
Ph.D. & 2 & \\
\hline Age of SME & & $3.0 \%$ \\
\hline Under 1 years & 3 & $12.5 \%$ \\
$1-5$ & 50 & $11.9 \%$ \\
$6-10$ & 13 & $11.9 \%$ \\
$11-15$ & 12 &
\end{tabular}

Note: $\mathrm{n}=101$.

\subsection{Measurement of Constructs}

The research model is composed of 9 constructs including strategic orientation, social influence, innovativeness, self-efficacy, complexity, security, PU, PEOU and BI. Table A1 in the Appendix A shows each construct measurement using multiple items. All the measurement items were adapted from previously validated and reliable measurement scales to preserve content validity. Each item is measured on a seven-point Likert scale from 1 (strongly disagree) to 7 (strongly agree).

\subsection{Strategic Orientation (SO)}

Referring to previous research, we use 10 items to assess SMEs' strategic orientation. Customer orientation is measured with 3 items [12,79,81]; competitor orientation is measured with 3 items [12,79,82]; and technology orientation is measured with 4 items [12,82,83]. For example: "we are likely to take advantage of the benefits new technology can bring to our business" [12]. After deleting 4 low-loading items, 6 items were used to run the check of the SO construct in the confirmatory factor analysis (CFA). The composite reliability (CR) of the construct was 0.95 .

\subsection{Social Influence (SI)}

Social influence was measured using a total of 6 items adapted from previous studies $[55-57,71,77]$. For example "People who are important to me are likely to recommend using cryptocurrency payment technology"'". The composite reliability (CR) of the construct is 0.92 . 


\subsection{SMEs Owner/Manager Characteristic Innovativeness and Self-Efficacy}

SMEs' owner/manager's innovativeness was assessed using a personal innovativeness scale from [62] consisting of 3 items (e.g., I know more about new products before other people do). The composite reliability (CR) of the construct is 0.90 . SMEs' owner/manager's self-efficacy was measured using 3 items adapted from [124] (also used in [125,126]. For example "I would feel comfortable using the cryptocurrency payment on my own; "if I wanted to, I could easily operate any of the steps in the cryptocurrency payment technology on my own"; "I would be able to use the equipment in the cryptocurrency payment even if there was no one around to show me how to use it". The composite reliability (CR) of the construct was 0.92 .

\subsection{Perceived Usefulness (PU) and Perceived Ease of Use (PEOU)}

The PU was measured using 6 items from [77] and [124]. The PEOU was measured using 3 items adapted from [77]. Every statement measuring PU and PEOU constructs was adapted to the topic of cryptocurrency payment technology. The composite reliability (CR) of the PU construct of total social capital was 0.91 and the PEOU construct of total social capital was 0.96 .

\subsection{Behavioral Intention (BI) to Adopt IT}

Behavioral intention to adopt cryptocurrency payment technology was assessed using 4 items adapted from the works of $[77,127]$. The composite reliability (CR) of the construct of total social capital was 0.95 .

\subsection{Technology Characteristics, Security and Convenience}

Security is conceptualized as perceived risk in the context of digital/online payments, consistent with the previous literature [91,128]. Security is measured with four items adapted from [129]. For example, "there are high chances of losing money if my business uses cryptocurrency payments". The composite reliability (CR) of the construct of total social capital was 0.96 . Convenience is measured using four items adopted from [62]. For example, "cryptocurrency payment is convenient because I can use it anytime". The composite reliability (CR) of the construct of total social capital was 0.95 .

\section{Analysis and Results}

This study used several stages of statistical analysis in testing the above hypotheses illustrated in the model (Figure 1). First, data screens, checks and dimension reduction are necessary procedures before determining the content of the construct. Exploratory factor analysis (EFA) was employed to determine the high-loading items of each dimension. Secondly, a confirmatory factor analysis (CFA) [130] was applied to test the measurement model and to check the relationships among constructs. Third, a structural equation modeling (SEM) analysis was used to estimate the causal effect among constructs and to test the research model. Compared to linear regression methods, SEM gives a clearer explanation of potential variables needed for the final model [131,132]. The method helps to verify the problems of common method variance (CMV), nonresponse bias and question response bias. It also examines the mediated or moderated relationships to indicate the strength of the relationships and if they are direct or indirect [131-133].

\subsection{Exploratory Factor Analysis}

Initially, principal axis factoring was used to find the common variance (correlation) of a set of variables and build the construct dimensions. We excluded low loading items from building the construct dimensions. Oblique rotation and Kaiser eigenvalues were utilized as a criterion (eigenvalues $\geq 1.0$ ) to form the nine dimensions. We deleted a few low-loading reflective items after implementing exploratory factor analysis. We are confident that the selected items present adequate measurements for each of the dimensions. 


\subsection{Reliability and Validity}

The following measures and criteria were used to check components' reliability and construct validity. The value of composite reliability (CR) verifies reliability if the value is greater than 0.7 . The value of average variance extracted (AVE) [134] verifies convergent validity when it is greater than 0.5; and the square root of AVE indicates discriminant validity when it is greater than inter-construct correlations $[132,135,136]$. As suggested by Fornell and Larcker (1981) regarding CR and AVE, we estimate the reliability and convergent validity by standardized regression weights (loadings) of items. We found that all CR values were above 0.7 , and the AVEs were higher than the 0.5 threshold, which indicates that the items reflect the concepts consistently (see Table 2). Thus, convergent validity was established and the measurement scale considered is reliable [132]. Comparison of the square root of AVE (on the diagonal) with the inter-construct correlations (see Table 2) indicate that the validity of the measurement scale and construct discriminant are adequate. 
Table 2. Composite reliability and validity correlations of study variables.

\begin{tabular}{|c|c|c|c|c|c|c|c|c|c|c|c|c|c|}
\hline & CR & AVE & MSV & $\operatorname{MaxR}(H)$ & SO & IN & SI & SE & PU & PEOU & BINT & SEC & CON \\
\hline $\mathrm{SO}$ & 0.95 & 0.74 & 0.46 & 0.96 & 0.86 & & & & & & & & \\
\hline IN & 0.9 & 0.76 & 0.54 & 0.93 & $0.598^{* * *}$ & 0.87 & & & & & & & \\
\hline SI & 0.92 & 0.71 & 0.7 & 0.96 & $0.495^{* * *}$ & $0.577^{* * *}$ & 0.85 & & & & & & \\
\hline SE & 0.92 & 0.8 & 0.7 & 0.93 & $0.558^{* * *}$ & $0.733^{* * *}$ & $0.660^{* * *}$ & 0.89 & & & & & \\
\hline PU & 0.91 & 0.76 & 0.58 & 0.94 & $0.676^{* * *}$ & $0.548^{* * *}$ & $0.651^{* * *}$ & $0.718^{* * *}$ & 0.87 & & & & \\
\hline PEOU & 0.96 & 0.88 & 0.78 & 0.97 & $0.600^{* * *}$ & $0.653^{* * *}$ & $0.768^{* * *}$ & $0.754^{* * *}$ & $0.733^{* * *}$ & 0.94 & & & \\
\hline BINT & 0.95 & 0.82 & 0.78 & 0.96 & $0.574^{* * *}$ & $0.661^{* * *}$ & $0.837^{* * *}$ & $0.789 * * *$ & $0.761^{* * *}$ & $0.885^{* * *}$ & 0.91 & & \\
\hline SEC & 0.96 & 0.84 & 0.09 & 0.96 & -0.155 & -0.082 & -0.153 & $-0.246^{*}$ & $-0.184+$ & $-0.304^{* *}$ & $-0.266^{*}$ & 0.92 & \\
\hline $\mathrm{CON}$ & 0.95 & 0.81 & 0.73 & 0.96 & $0.654^{* * *}$ & $0.662^{* * *}$ & $0.729^{* * *}$ & $0.837^{* * *}$ & $0.715^{* * *}$ & $0.816^{* * *}$ & $0.852^{* * *}$ & $-0.203+$ & 0.9 \\
\hline
\end{tabular}




\subsection{CFA/SEM Model Analysis}

Before testing the hypotheses of the model, it is necessary to examine a common method bias $(\mathrm{CMB})$ that causes high correlation among constructs. We used a common latent factor (CLF) to capture the common variance among all observed variables in the model. We added a marker variable (security) and identified a significant method bias in our model indicated by a significant chi-square difference between a zero-constrained and unconstrained model. Therefore, we controlled for the security factor in our structural analyses $[137,138]$.

Next, we checked the overall measurement model using the maximum likelihood method to estimate the level of model fit. The results of the model fit showed that $\chi 2 / \mathrm{df}$ was 1.825 ( $\chi 2=540.337$, $\mathrm{df}=296, p<0.000$ ), Confirmatory factor analysis $=0.925$ and Standardized Root Mean Square Residual $=0.059$, suggesting an adequate model fit [130]. Based on our assumptions, there are four covariance matrices composed of independent variables: strategy orientation, social influence, innovativeness and self-efficacy. Behavioral intention (BI) to adopt IT is a dependent variable; perceived usefulness (PU) and perceived ease of use (PEOU) are two mediator variables. In addition, we assume security, convenience, age and gender have a moderating effect and consider them as potentially confounding variables in the model.

The results of hypothesis testing are presented in Table 3. Eight regression coefficients are statistically significant (Figure 2). Firstly, four independent variables all have a significant effect on two mediator variables. Strategy orientation (SO) and social influence (SI) have a statistically significant effect on perceived usefulness (PU), both significant at a $1 \%$ level. Innovativeness and self-efficacy have a statistically significant effect on perceived ease of use (PEOU), significant at $10 \%$ and $1 \%$, respectively. The standardized regression weights are as follows: (1) from SO to PU, r $=0.186, p \leq 0.001$; (2) from SI to PU, $r=0.330, p \leq 0.001$; (3) from innovativeness to PEOU, $r=0.163, p \leq 0.1$ and (4) from self-efficacy to PEOU, $r=0.674, p \leq 0.001$. Secondly, one independent variable, SI, has a significant effect on dependent variable BI. The standardized regression weight from SI to BI are $\mathrm{r}=0.546, p \leq 0.001$. Third, the relationship between mediators is significant. PEOU has a significant effect on PU with a standardized regression weight of $r=0.614, p \leq 0.001$. Finally, two mediators have a significant effect on the dependent variable. The standardized regression weight from PU to BI is $r=675 p \leq 0.001$ and from PEOU to $\mathrm{BI}$ is $\mathrm{r}=859 p \leq 0.001$.

Table 3. Results of mediation test.

\begin{tabular}{cccc}
\hline Hypothesis & Direct Effect & Indirect Effect & Result \\
\hline $\mathrm{SO} \rightarrow \mathrm{PU} \rightarrow \mathrm{BI}$ & $-0.044(\mathrm{~ns})$ & $0.131^{* * *}$ & Full mediation \\
$\mathrm{SI} \rightarrow \mathrm{PU} \rightarrow \mathrm{BI}$ & $0.550^{* *}$ & $0.231^{* *}$ & Partial mediation \\
$\mathrm{IN} \rightarrow \mathrm{PEOU} \rightarrow \mathrm{BI}$ & $-0.035(\mathrm{~ns})$ & $0.127(\mathrm{~ns})$ & No mediation \\
$\mathrm{SE} \rightarrow \mathrm{PEOU} \rightarrow \mathrm{BI}$ & $0.086(\mathrm{~ns})$ & $0.552^{* *}$ & Full mediation
\end{tabular}

Note: SO: Strategic Orientation; SI: Social Influence; IN: Innovativeness; SE: Self-Efficacy; PU: Perceived Usefulness; PEOU: Perceived ease to Use; BI: Behavioral intention to adopt IT; ${ }^{* * *} p<0.001$; ${ }^{* *} p<0.01$; ns = "not significant" 


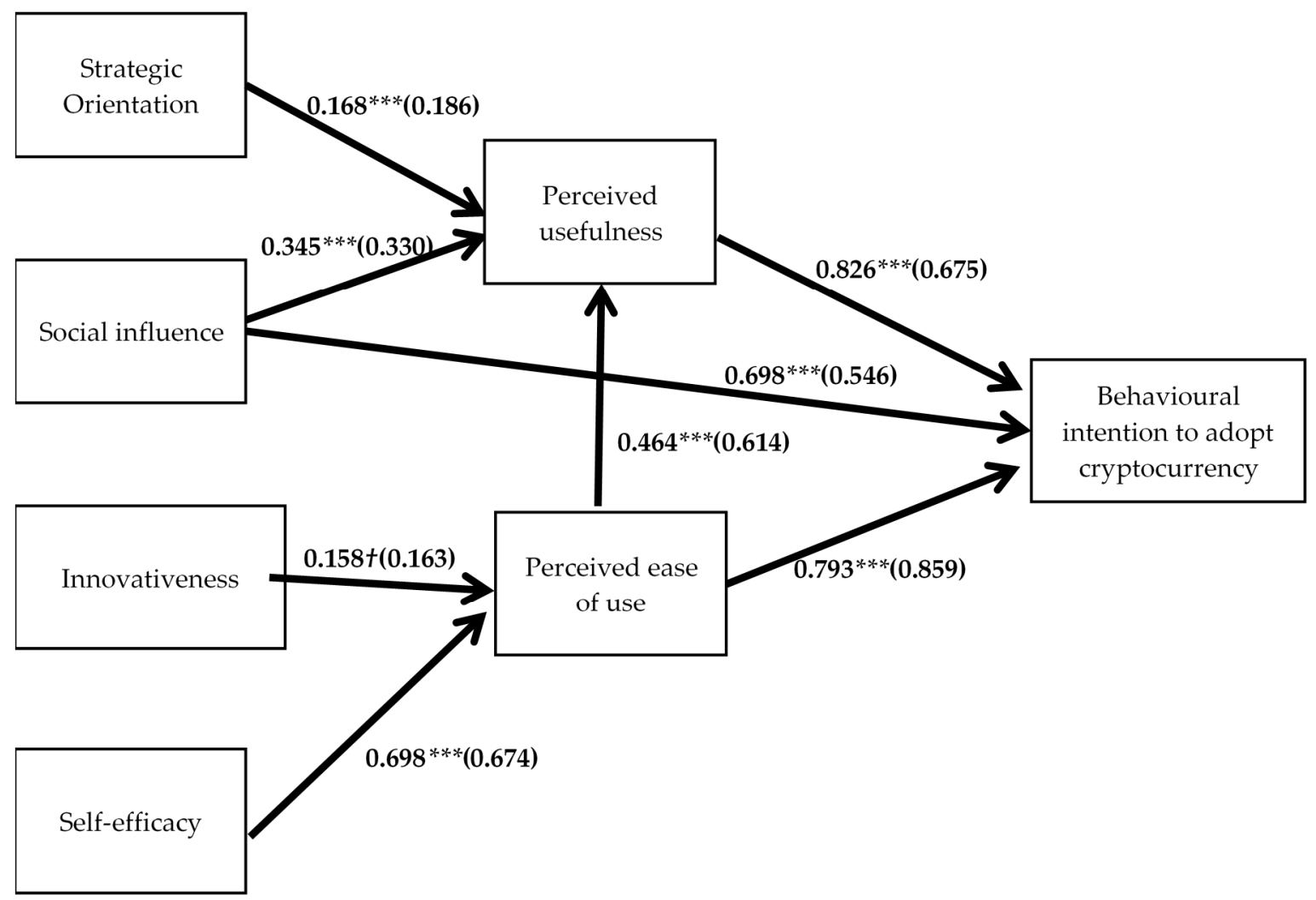

Figure 2. SEM results for path analysis of variables Note: Standardized coefficients are provided in parentheses. For the sake of parsimony, we did not present the effects of control variables (i.e., Age, Gender, Income, and Education level) here; $+p<0.1{ }^{* * *} p<0.001$.

Due to the model including four independent variables and two mediator variables, we conducted the direct and indirect effect analyses separately. The results show the following: PU mediates the relationship from SO to $\mathrm{BI}$ and from SI to $\mathrm{BI}$; and PEOU mediates the relationship from self-efficacy to BI. However, PEOU was not found to mediate the relationship from innovativeness to BI (See Table 3).

\section{Discussion and Conclusions}

This study seeks to extend our understanding of cryptocurrency payments adoption by extending TAM to the context of SMEs in tourism and hospitality. The research model in this study enhances the theoretical foundations of TAM through the integration of both internal and external forces shaping the adoption behavior with consideration of characteristics of SMEs in tourism and hospitality. This study theorizes the effect of such internal factors as SMEs' strategic orientation, owner/manager's individual characteristics and external factors-social influence and technology characteristics on cryptocurrency payments adoption. We found that the effect of social influence, strategic orientation and SMEs' owner/manager's individual characteristics have a significant effect on the behavioral intention to adopt cryptocurrency payments. However, the moderating effects of technology characteristics, gender and age on BI were not significant. The significant effect of social influence on PU and BI could be explained by a strong collective culture in Taiwan, which is dominant in shaping behavior $[139,140]$. The absence of a significant moderating effect of gender and age could also be due to collectivist values of Taiwanese culture, where individuals are more likely to comply with the opinions of salient others regardless of age and gender [93,141].

This paper makes a few important contributions to the research. First, this is one of the first studies that empirically examine the adoption of new blockchain technology with the example of cryptocurrency payments. Generally, there are very few empirical studies on IT adoption in the tourism 
and hospitality literature [13,30]. Second, several authors have suggested that the TAM model and its extensions are applicable to the adoption of cryptocurrency payments [31,33]. This study confirmed that PU and PEOU are salient factors in the behavioral intention to adopt cryptocurrency payments, consistent with prior TAM theories [62,77]. Additionally, the present work is one of the few empirical investigations of the joint effect of internal and external factors influencing SMEs' IT adoption behavior considering specific industry characteristics.

Considering limited research that has examined the topic of blockchain adoption among SMEs, we propose specific areas for future research to better understand the relationship between cryptocurrency payments and SMEs' performance. Although we have acknowledged the roles of the SMEs' legislative and technological environments affecting cryptocurrency payment adoption, we did not explicitly measure this. Future studies could explore wider implications of blockchain technology among SMEs as a way to attract and respond to customer demands and sustain pressure from large established and new players (e.g., Airbnb) in tourism and hospitality. Future studies could also employ other analytical methods, such as spatial analysis [142], in order to analyze the diffusion of blockchain innovation.

SMEs face challenges from the innovations embraced by the younger "digitally native" generation [92]. Alternative payment technology, such as cryptocurrency payments, may disrupt traditional financial payments, and its adoption by SMEs becomes vital for their successful competitiveness and development. However, research in SMEs and tourism and hospitality is falling behind in addressing this issue. This study highlights this key issue and makes an important step towards informing relevant stakeholders, government representatives, industry professionals and policy makers. Relevant stakeholders could develop strategies, provide early training programs and foster development of an environment that supports SMEs' IT adoption and as a result facilitate their sustainable development and competitiveness.

Author Contributions: All of the authors contributed equally in the development of the present paper. All of the phases of the paper development proper have been discussed and worked on by the authors. All authors have read and agreed to the published version of the manuscript.

Funding: This research received no external funding.

Acknowledgments: The authors are very grateful to all the participants from the Hualien County tourism and hospitality firms association who filled in the questionnaire. We would like to thank the anonymous reviewers for their helpful comments and suggestions, which improved the quality of this paper greatly.

Conflicts of Interest: The authors declare no conflict of interest. 


\section{Appendix A}

Table A1. Summary of measurement scale, CR and AVE.

\begin{tabular}{|c|c|c|c|}
\hline Construct. & Measurement (Items) & Mean (s.d.) & Loadings \\
\hline \multicolumn{4}{|c|}{ Strategic Orientation, Composite Reliability $(C R)=0.95$, Average Variance Extracted $(\mathrm{AVE})=0.74$} \\
\hline & In our business we put customer interest first. & $5.35(1.49)$ & 0.800 \\
\hline & We will adopt new technology if it can improve our customer service. & $5.39(1.48)$ & 0.860 \\
\hline & It is important for us to keep an eye and respond to our competitors behavior. & $5.49(1.38)$ & 0.770 \\
\hline & Some new technologies adoption give us competitive advantage. & $5.39(1.54)$ & 0.906 \\
\hline & We are able (willing) to learn new technology usage so we can add it to our service. & $5.28(1.58)$ & 0.943 \\
\hline & We can use our technical knowledge to use new systems in order to respond and meet our customer needs. & $5.33(1.58)$ & 0.871 \\
\hline \multicolumn{4}{|c|}{ Social Influence, Composite Reliability $(C R)=0.92$, Average Variance Extracted $(A V E)=0.71$} \\
\hline & $\begin{array}{l}\text { People who are important to me (family, peers, competitors, friends, colleagues etc.) are likely to } \\
\text { recommend using Cryptocurrency payment technology. }\end{array}$ & $3.92(1.71)$ & 0.924 \\
\hline & $\begin{array}{l}\text { People who are important to me would probably suggest that I should use Cryptocurrency payment } \\
\text { technology. }\end{array}$ & $3.82(1.72)$ & 0.957 \\
\hline & People who influence my behavior would expect me to use Cryptocurrency payment technology. & $3.87(1.76)$ & 0.937 \\
\hline & $\begin{array}{l}\text { The people in my business environment who use Cryptocurrency payment are more prestigious than } \\
\text { those who do not use it. }\end{array}$ & $3.72(1.75)$ & 0.634 \\
\hline & The people in my business environment who use Cryptocurrency payment have a superior profile. & $3.69(1.65)$ & 0.721 \\
\hline \multicolumn{4}{|c|}{ Innovativeness; SMEs owner/manager characteristic, Composite Reliability $(\mathrm{CR})=0.90$, Average Variance Extracted $(\mathrm{AVE})=0.76$} \\
\hline & I know more about new products and technology before other people do. & $4.05(1.85)$ & 0.945 \\
\hline & I am usually among the first to try new products and technology. & $3.76(1.80)$ & 0.862 \\
\hline & New technology and products excite me & $4.63(1.88)$ & 0.793 \\
\hline \multicolumn{4}{|c|}{ Self-Efficacy; SMEs owner/manager characteristic, Composite Reliability $(C R)=0.92$, Average Variance Extracted $(\mathrm{AVE})=0.80$} \\
\hline & I would feel comfortable using the Cryptocurrency payment on my own. & $4.36(1.91)$ & 0.858 \\
\hline & $\begin{array}{l}\text { If I wanted to, I could easily operate any of the steps in the Cryptocurrency payment technology on my } \\
\text { own. }\end{array}$ & $4.51(2.01)$ & 0.911 \\
\hline & $\begin{array}{l}\text { I would be able to use the equipment in the Cryptocurrency payment even if there was no one around to } \\
\text { show me how to use it. }\end{array}$ & $4.01(1.89)$ & 0.910 \\
\hline \multicolumn{4}{|c|}{ Perceived usefulness (PU), Composite Reliability $(\mathrm{CR})=0.91$, Average Variance Extracted $(\mathrm{AVE})=0.76$} \\
\hline & Cryptocurrency payment technology helps make payments more effectively. & $4.60(1.64)$ & 0.957 \\
\hline & Using Cryptocurrency payment technology would enable to make payment more quickly. & $4.87(1.57)$ & 0.831 \\
\hline & Cryptocurrency payment is a useful payment method. & $4.87(1.57)$ & 0.825 \\
\hline
\end{tabular}


Table A1. Cont.

\begin{tabular}{|c|c|c|c|}
\hline Construct. & Measurement (Items) & Mean (s.d.) & Loadings \\
\hline \multicolumn{4}{|c|}{ Perceived Ease of Use (PEOU), Composite Reliability $(\mathrm{CR})=0.96$, Average Variance Extracted $(\mathrm{AVE})=0.88$} \\
\hline & My interaction with Cryptocurrency payment procedure is generally clear and understandable & $4.24(1.50)$ & 0.971 \\
\hline & I find Cryptocurrency payment technology is easy to use & $4.16(1.71)$ & 0.866 \\
\hline & It is easy for me to become skillful at using Cryptocurrency payment & $4.24(1.69)$ & 0.968 \\
\hline \multicolumn{4}{|c|}{ Security, Composite Reliability $(C R)=0.96$, Average Variance Extracted $(\mathrm{AVE})=0.84$} \\
\hline & There are high chances of losing money if my business use Cryptocurrency payment technology. & $4.44(1.58)$ & 0.931 \\
\hline & Using Cryptocurrency payment technology subjects my business to potential fraud. & $4.88(1.60)$ & 0.891 \\
\hline & $\begin{array}{l}\text { My signing up for and using Cryptocurrency payment technology would lead to probable financial loss } \\
\text { for my business. }\end{array}$ & $4.50(1.61)$ & 0.941 \\
\hline & Using Cryptocurrency payment service subjects my business to financial risk. & $4.37(1.65)$ & 0.905 \\
\hline \multicolumn{4}{|c|}{ Convenience, Composite Reliability $(\mathrm{CR})=0.95$, Average Variance Extracted $(\mathrm{AVE})=0.81$} \\
\hline & I have the resources necessary to use Cryptocurrency payment system in my business & $4.26(1.77)$ & 0.896 \\
\hline & I have the knowledge necessary to use Cryptocurrency payment technology in my business & $4.06(1.91)$ & 0.939 \\
\hline & Cryptocurrency payment is compatible with other payment technologies we use in our business. & $4.03(1.88)$ & 0.954 \\
\hline & I can get help from others when I have difficulties using Cryptocurrency payment system. & $4.41(1.81)$ & 0.807 \\
\hline \multicolumn{4}{|c|}{ Behavioral intention to adopt IT, Composite Reliability $(C R)=0.95$, Average Variance Extracted $($ AVE $)=0.82$} \\
\hline & I think I will use Cryptocurrency payment technology in my business in the near future. & $4.09(1.74)$ & 0.968 \\
\hline & I plan to use Cryptocurrency payment technology in the next few months. & $3.70(1.90)$ & 0.866 \\
\hline & I intent to add Cryptocurrency payment to my business payment services. & $3.95(1.83)$ & 0.902 \\
\hline & Given a chance I predict that I should use Cryptocurrency payment. & $4.39(1.78)$ & 0.883 \\
\hline
\end{tabular}




\section{References}

1. Nyheim, P.; Connolly, D. Technology Strategies for the Hospitality Industry; Prentice Hall Press: Upper Saddle River, NJ, USA, 2011.

2. Qureshi, S.; York, A.S. Information Technology Adoption by Small Businesses in Minority and Ethnic Communities. In Proceedings of the 41st Annual Hawaii International Conference on System Sciences (HICSS 2008), Waikoloa, HI, USA, 7-10 January 2008; p. 447.

3. Qureshil, S.; Kamal, M.; Wolcott, P. Information technology interventions for growth and competitiveness in micro-enterprises. Int. J. Enterp. Inf. Syst. IJEIS 2009, 5, 71-95. [CrossRef]

4. Schreiner, M.; Woller, G. Microenterprise Development Programs in the United States and in the Developing World. World Dev. 2003, 31, 1567-1580. [CrossRef]

5. Riemenschneider, C.K.; Harrison, D.A.; Mykytyn, P.P. Understanding it adoption decisions in small business: Integrating current theories. Inf. Manag. 2003, 40, 269-285. [CrossRef]

6. La Porta, R.; Lopez-De-Silanes, F.; Shleifer, A. Corporate Ownership around the World. J. Financ. 1999, 54, 471-517. [CrossRef]

7. Amit, R.H.; Ding, Y.; Villalonga, B.; Hua, Z. The Role of Institutional Development in the Prevalence and Value of Family Firms. In Proceedings of the Finance and Corporate Governance Conference, Luna Park, Sydney, Australia, 15-16 November 2010.

8. Klein, S.B. Family Businesses in Germany: Significance and Structure. Fam. Bus. Rev. 2000, 13, $157-181$. [CrossRef]

9. Xiong, J.; Qureshi, S.; Najjar, L. Factors that affect information and communication technology adoption by small businesses in China. 2013. Available online: https://digitalcommons.unomaha.edu/cgi/viewcontent. cgi? article $=1044 \&$ context $=$ isqafacproc (accessed on 30 August 2019).

10. De Massis, A.; Sharma, P.; Chua, J.H.; Chrisman, J.J. Family Business Studies: An. Annotated Bibliography; Edward Elgar Publishing: Cheltenham, UK, 2012.

11. Cassia, L.; De Massis, A.; Pizzurno, E. Strategic innovation and new product development in family firms: An empirically grounded theoretical framework. Int. J. Entrep. Behav. Res. 2012, 18, 198-232. [CrossRef]

12. Wang, Y.; Qualls, W. Towards a theoretical model of technology adoption in hospitality organizations. Int. J. Hosp. Manag. 2007, 26, 560-573. [CrossRef]

13. Filimonau, V.; Naumova, E. The blockchain technology and the scope of its application in hospitality operations. Int. J. Hosp. Manag. 2019, 102383. [CrossRef]

14. Cetin, G.; Demirciftci, T.; Bilgihan, A. Meeting revenue management challenges: Knowledge, skills and abilities. Int. J. Hosp. Manag. 2016, 57, 132-142. [CrossRef]

15. Lam, C.; Ho, G.K.; Law, R.; Law, C.H.R. How can Asian hotel companies remain internationally competitive? Int. J. Contemp. Hosp. Manag. 2015, 27, 827-852. [CrossRef]

16. Martínez, P.; Del Bosque, I.R. CSR and customer loyalty: The roles of trust, customer identification with the company and satisfaction. Int. J. Hosp. Manag. 2013, 35, 89-99. [CrossRef]

17. Narteh, B.; Agbemabiese, G.C.; Kodua, P.; Braimah, M. Relationship Marketing and Customer Loyalty: Evidence from the Ghanaian Luxury Hotel Industry. J. Hosp. Mark. Manag. 2013, 22, 407-436. [CrossRef]

18. Qiu, H.; Ye, B.H.; Bai, B.; Wang, W.H. Do the roles of switching barriers on customer loyalty vary for different types of hotels? Int. J. Hosp. Manag. 2015, 46, 89-98. [CrossRef]

19. United Nations Environment Programme. Division of Technology, \& Economics. In Making Tourism More Sustainable: A Guide for Policy Makers; World Tourism Organization Publications: Madrid, Spain, 2005.

20. Akbar, S.; Hallak, R. Identifying Business Practices Promoting Sustainability in Aboriginal Tourism Enterprises in Remote Australia. Sustainability 2019, 11, 4589. [CrossRef]

21. Önder, I.; Wöber, K.; Zekan, B.J.T.E. Towards a sustainable urban tourism development in Europe: The role of benchmarking and tourism management information systems-A partial model of destination competitiveness. Tour. Econ. 2017, 23, 243-259. [CrossRef]

22. Organisation for Economic Co-operation and Development. OECD Tourism Trends and Policies 2018; OECD: Paris, France, 2018.

23. Xia, B.; Dong, S.; Ba, D.; Li, Y.; Li, F.; Liu, H.; Li, Z.; Zhao, M. Research on the Spatial Differentiation and Driving Factors of Tourism Enterprises' Efficiency: Chinese Scenic Spots, Travel Agencies, and Hotels. Sustainability 2018, 10, 901. [CrossRef] 
24. Roussou, I.; Stiakakis, E. Adoption of Digital Currencies by Companies in the European Union: A Research Model combining DOI and TAM. In Proceedings of the 4 th International Conference on Contemporary Marketing Issues (ICCMI), Heraklion, Greece, 22-24 June 2016; p. 163.

25. Kwok, A.O.J.; Koh, S.G.M. Is blockchain technology a watershed for tourism development? J. Curr. Issues Tour. 2019, 22, 2447-2452. [CrossRef]

26. Huckle, S.; Bhattacharya, R.; White, M.; Beloff, N.; Huckle, S. Internet of Things, Blockchain and Shared Economy Applications. Procedia Comput. Sci. 2016, 98, 461-466. [CrossRef]

27. Önder, I.; Treiblmaier, H. Blockchain and tourism: Three research propositions. Ann. Tour. Res. 2018, 72, 180-182. [CrossRef]

28. Calvaresi, D.; Leis, M.; Dubovitskaya, A.; Schegg, R.; Schumacher, M. Trust in Tourism via Blockchain Technology: Results from a Systematic Review. In Information and Communication Technologies in Tourism 2019; Springer: New York, NY, USA, 2019; pp. 304-317.

29. Leung, D.; Dickinger, A. Use of Bitcoin in Online Travel Product Shopping: The European Perspective. In Information and Communication Technologies in Tourism 2017; Springer Science and Business Media LLC: Berlin, Germany, 2017; pp. 741-754.

30. Rad, M.S.; Nilashi, M.; Dahlan, H.M. Information technology adoption: A review of the literature and classification. Univers. Access Inf. Soc. 2018, 17, 361-390.

31. Lennon, M.M.; Folkinshteyn, D. From Bit Valley to Bitcoin: The NASDAQ Odyssey. Glob. J. Bus. Res. 2017, 11, 85-103.

32. Meiklejohn, S.; Pomarole, M.; Jordan, G.; Levchenko, K.; McCoy, D.; Voelker, G.M.; Savage, S. A fistful of bitcoins: Characterizing payments among men with no names. In Proceedings of the 2013 Conference on Internet Measurement Conference, Barcelona, Spain, 23-25 October 2013; pp. 127-140.

33. Lou, A.T.; Li, E.Y. Integrating Innovation Diffusion Theory and the Technology Acceptance Model: The adoption of blockchain technology from business managers' perspective. In Proceedings of the 17th International Conference on Electronic Business, Dubai, UAE, 4-8 December 2017; pp. 299-302.

34. Davis, F.D. Perceived usefulness, perceived ease of use, and user acceptance of information technology. MIS Q. 1989, 13, 319-340. [CrossRef]

35. Kim, K.J.; Shin, D.-H. An acceptance model for smart watches: Implications for the adoption of future wearable technology. Emerald Insight 2015, 25, 527-541. [CrossRef]

36. Luarn, P.; Lin, H.-H. Toward an understanding of the behavioral intention to use mobile banking. Comput. Hum. Behav. 2005, 21, 873-891. [CrossRef]

37. Thong, J.Y.; Yap, C. CEO characteristics, organizational characteristics and information technology adoption in small businesses. Omega 1995, 23, 429-442. [CrossRef]

38. Cragg, P.B.; Zinatelli, N. The evolution of information systems in small firms. Inf. Manag. 1995, 29, 1-8. [CrossRef]

39. Lybaert, N. The Information Use in a SME: Its Importance and Some Elements of Influence. Small Bus. Econ. 1998, 10, 171-191. [CrossRef]

40. Andries, P.; DeBackere, K. Adaptation in new technology-based ventures: Insights at the company level. Int. J. Manag. Rev. 2006, 8, 91-112. [CrossRef]

41. Levy, M.; Powell, P.; Yetton, P. SMEs: Aligning is and the Strategic Context. J. Inf. Technol. 2001, 16, $133-144$. [CrossRef]

42. Nguyen, T.H. Information technology adoption in SMEs: An integrated framework. Int. J. Entrep. Behav. Res. 2009, 15, 162-186. [CrossRef]

43. Bruque, S.; Moyano, J. Organisational determinants of information technology adoption and implementation in SMEs: The case of family and cooperative firms. Technovation 2007, 27, 241-253. [CrossRef]

44. Heart, T.; Pliskin, N. Business-to-business eCommerce of information systems: Two cases of ASP-to-SME eRental. INFOR Inf. Syst. Oper. Res. 2002, 40, 23-34. [CrossRef]

45. Ghobakhloo, M.; Arias-Aranda, D.; Benitez-Amado, J. Adoption of e-commerce applications in SMEs. Ind. Manag. Data Syst. 2011, 111, 1238-1269. [CrossRef]

46. Lopez-Fernandez, M.C.; Serrano-Bedia, A.M.; Gómez-López, R. Determinants of innovation decision in small and medium-sized family enterprises. J. Small Bus. Enterp. Dev. 2016, 23, 408-427. [CrossRef]

47. Vega-Jurado, J.; Gutiérrez-Gracia, A.; Fernández-De-Lucio, I.; Manjarrés-Henríquez, L. The effect of external and internal factors on firms' product innovation. Res. Policy 2008, 37, 616-632. [CrossRef] 
48. Coronado, D.; Acosta, M.; Fernández, A. Attitudes to innovation in peripheral economic regions. Res. Policy 2008, 37, 1009-1021. [CrossRef]

49. Madrid-Guijarro, A.; Garcia, D.; Van Auken, H. Barriers to Innovation among Spanish Manufacturing SMEs. J. Small Bus. Manag. 2009, 47, 465-488. [CrossRef]

50. Gudmundson, D.; Tower, C.B.; Hartman, E.A. Innovation in small businesses: Culture and ownership structure do matter. J. Dev. Entrep. 2003, 8, 1-17.

51. Chrisman, J.J.; Patel, P.C. Variations in R\&D Investments of Family and Nonfamily Firms: Behavioral Agency and Myopic Loss Aversion Perspectives. Acad. Manag. J. 2012, 55, 976-997.

52. Classen, H.; Fogarty, M. Avoiding Turbulence in the Cloud: Licensing and Contractual Issues for Licensors, Cloud Providers and End Users. Comput. Internet Lawyer 2012, 29, 1-15.

53. Fishbein, M.; Ajzen, I. Belief, Attitude, Intention and Behaviour: An. Introduction to Theory and Research; Addison-Wesley: Boston, MA, USA, 1975.

54. Ajzen, I. The theory of planned behavior. Organ. Behav. Hum. Decis. Process. 1991, 50, 179-211. [CrossRef]

55. Venkatesh, V.; Davis, F.D. A Theoretical Extension of the Technology Acceptance Model: Four Longitudinal Field Studies. Manag. Sci. 2000, 46, 186-204. [CrossRef]

56. Venkatesh, V.; Bala, H. Technology Acceptance Model 3 and a Research Agenda on Interventions. Decis. Sci. 2008, 39, 273-315. [CrossRef]

57. Venkatesh, V.; Morris, M.G.; Davis, G.B.; Davis, F.D. User acceptance of information technology: Toward a unified view. MIS Q. 2003, 27, 425-478. [CrossRef]

58. Turner, R.; Ledwith, A.; Kelly, J. Project management in small to medium-sized enterprises: Matching processes to the nature of the firm. Int. J. Proj. Manag. 2010, 28, 744-755. [CrossRef]

59. Shin, J.; Park, Y. Brownian agent-based technology forecasting. Technol. Forecast. Soc. Chang. 2009, 76, 1078-1091. [CrossRef]

60. King, W.R.; He, J. A meta-analysis of the technology acceptance model. Inf. Manag. 2006, 43, 740-755. [CrossRef]

61. Klopping, I.M.; McKinney, E. Extending the technology acceptance model and the task-technology fit model to consumer e-commerce. Inf. Technol. Learn. Perform. J. 2004, 22, 35-48.

62. Kim, C.; Mirusmonov, M.; Lee, I. An empirical examination of factors influencing the intention to use mobile payment. Comput. Hum. Behav. 2010, 26, 310-322. [CrossRef]

63. Hernández García, Á.; Iglesias Pradas, S.; Chaparro Pelaez, J.J.; Pascual Miguel, F.J. Exploring the attitudes and intentions of non-shoppers in the acceptance of e-commerce. J. Univers. Comput. Sci. 2011, 17, 1314-1328.

64. Lee, M.-C. Factors influencing the adoption of internet banking: An integration of TAM and TPB with perceived risk and perceived benefit. Electron. Commer. Res. Appl. 2009, 8, 130-141. [CrossRef]

65. Zmud, R.W. Individual Differences and MIS Success: A Review of the Empirical Literature. Manag. Sci. 1979, 25, 966-979. [CrossRef]

66. Nelson, D.L. Individual Adjustment to Information-Driven Technologies: A Critical Review. MIS Q. 1990, 14, 79. [CrossRef]

67. Agarwal, R.; Prasad, J. Are Individual Differences Germane to the Acceptance of New Information Technologies? Decis. Sci. 1999, 30, 361-391. [CrossRef]

68. Mallat, N. Exploring consumer adoption of mobile payments-A qualitative study. J. Strateg. Inf. Syst. 2007, 16, 413-432. [CrossRef]

69. Ondrus, J.; Pigneur, Y. Towards a holistic analysis of mobile payments: A multiple perspectives approach. Electron. Commer. Res. Appl. 2006, 5, 246-257. [CrossRef]

70. Venkatesh, V.; Thong, J.; Xu, X. The Hong Kong Polytechnic University. Unified Theory of Acceptance and Use of Technology: A Synthesis and the Road Ahead. J. Assoc. Inf. Syst. 2016, 17, 328-376.

71. Moore, G.C.; Benbasat, I. Development of an Instrument to Measure the Perceptions of Adopting an Information Technology Innovation. Inf. Syst. Res. 1991, 2, 192-222. [CrossRef]

72. Fishbein, M.; Ajzen, I. Misconceptions about the Fishbein model: Reflections on a study by Songer-Nocks. J. Exp. Soc. Psychol. 1976, 12, 579-584. [CrossRef]

73. Lucas, H.C.; Spitler, V. Implementation in a world of workstations and networks. Inf. Manag. 2000, 38, 119-128. [CrossRef]

74. Fenollar, P.; Cuestas, P. Cómo es el innovador? Rasgos de la personalidad como antecedentes. In Proceedings of the XXII Congreso Nacional de Marketing, Oviedo, Spain, 22-24 September 2010; p. 101. 
75. DiPietro, R.B.; Wang, Y. (Raymond) Key issues for ICT applications: Impacts and implications for hospitality operations. Worldw. Hosp. Tour. Themes 2010, 2, 49-67. [CrossRef]

76. Ghobakhloo, M.; Hong, T.S.; Sabouri, M.S.; Zulkifli, N. Strategies for Successful Information Technology Adoption in Small and Medium-sized Enterprises. Information 2012, 3, 36-67. [CrossRef]

77. Venkatesh, V.; Thong, J.Y.L.; Xu, X. Consumer Acceptance and Use of Information Technology: Extending the Unified Theory of Acceptance and Use of Technology. MIS Q. 2012, 36, 157-178. [CrossRef]

78. Dickinger, A.; Arami, M.; Meyer, D. The role of perceived enjoyment and social norm in the adoption of technology with network externalities. Eur. J. Inf. Syst. 2008, 17, 4-11. [CrossRef]

79. Narver, J.C.; Slater, S.F. The Effect of a Market Orientation on Business Profitability. J. Mark. 1990, 54, $20-35$. [CrossRef]

80. Caldeira, M.M.; Ward, J.M. Using resource-based theory to interpret the successful adoption and use of information systems and technology in manufacturing small and medium-sized enterprises. Eur. J. Inf. Syst. 2003, 12, 127-141. [CrossRef]

81. Deshpandé, R.; Farley, J.U.; Webster, F.E., Jr. Corporate culture, customer orientation, and innovativeness in Japanese firms: A quadrad analysis. J. Mark. 1993, 57, 23-37. [CrossRef]

82. Cooper, R.G. Debunking the Myths of New Product Development. Res. Manag. 1994, 37, 40-50. [CrossRef]

83. Kanter, R.M. Three Tiers for Innovation Research. Commun. Res. 1988, 15, 509-523. [CrossRef]

84. Drew, S. Strategic Uses of E-Commerce by SMEs in the East of England. Eur. Manag. J. 2003, 21, 79-88. [CrossRef]

85. Pontikakis, D.; Lin, Y.; Demirbas, D. History matters in Greece: The adoption of Internet-enabled computers by small and medium sized enterprises. Inf. Econ. Policy 2006, 18, 332-358. [CrossRef]

86. Maruping, L.M.; Bala, H.; Venkatesh, V.; Brown, S.A. Going beyond intention: Integrating behavioral expectation into the unified theory of acceptance and use of technology. J. Assoc. Inf. Sci. Technol. 2017, 68, 623-637. [CrossRef]

87. Fang, K. An analysis of electronic-mail usage. Comput. Hum. Behav. 1998, 14, 349-374. [CrossRef]

88. Lee, R.; Murphy, J.; Swilley, E. The moderating influence of hedonic consumption in an extended theory of planned behaviour. Serv. Ind. J. 2009, 29, 539-555. [CrossRef]

89. Kim, H.-W.; Chan, H.C.; Gupta, S. Value-based Adoption of Mobile Internet: An empirical investigation. Decis. Support. Syst. 2007, 43, 111-126. [CrossRef]

90. Khalilzadeh, J.; Ozturk, A.B.; Bilgihan, A. Security-related factors in extended UTAUT model for NFC based mobile payment in the restaurant industry. Comput. Hum. Behav. 2017, 70, 460-474. [CrossRef]

91. Yang, S.; Lu, Y.; Gupta, S.; Cao, Y.; Zhang, R. Mobile payment services adoption across time: An empirical study of the effects of behavioral beliefs, social influences, and personal traits. Comput. Hum. Behav. 2012, 28, 129-142. [CrossRef]

92. Koenig-Lewis, N.; Marquet, M.; Palmer, A.; Zhao, A.L. Enjoyment and social influence: Predicting mobile payment adoption. Serv. Ind. J. 2015, 35, 537-554. [CrossRef]

93. Venkatesh, V.; Zhang, X. Unified Theory of Acceptance and Use of Technology: U.S. vs. China. J. Glob. Inf. Technol. Manag. 2010, 13, 5-27. [CrossRef]

94. Chen, C.; Czerwinski, M.; Macredie, R. Individual differences in virtual environments? Introduction and overview. J. Am. Soc. Inf. Sci. 2000, 51, 499-507. [CrossRef]

95. Campanella, F.; Serino, L. Do personal characteristics of manager affect Smes' Access to Bank Loan? Int. J. Econ. Bus. Financ. 2019, 6, 1-14.

96. Taalika, S. Assessing the managerial influence as a facilitating factor in innovation adoption process. In Proceedings of the IAMOT Conference, Washington, DC, USA, 3-7 April 2004.

97. Petroni, A.; Rizzi, A. Antecedents of MRP adoption in small and medium-sized firms. Benchmarking Int. J. 2001, 8, 144-156. [CrossRef]

98. Hashim, J. Information communication technology (ICT) adoption among SME owners in Malaysia. Int. J. Bus. Inf. 2007, 2, 221-240.

99. Premkumar, G.; Roberts, M. Adoption of new information technologies in rural small businesses. Omega 1999, 27, 467-484. [CrossRef]

100. Dholakia, R.R.; Kshetri, N. Factors Impacting the Adoption of the Internet among SMEs. Small Bus. Econ. 2004, 23, 311-322. [CrossRef] 
101. Chang, M.K.; Cheung, W.; Lai, V.S. Literature derived reference models for the adoption of online shopping. Inf. Manag 2005, 42, 543-559. [CrossRef]

102. Yi, M.Y.; Fiedler, K.D.; Park, J.S. Understanding the Role of Individual Innovativeness in the Acceptance of IT-Based Innovations: Comparative Analyses of Models and Measures. Decis. Sci. 2006, 37, 393-426. [CrossRef]

103. Nov, O.; Ye, C. Users' personality and perceived ease of use of digital libraries: The case for resistance to change. J. Am. Soc. Inf. Sci. Technol. 2008, 59, 845-851. [CrossRef]

104. Bandura, A. The Explanatory and Predictive Scope of Self-Efficacy Theory. J. Soc. Clin. Psychol. 1986, 4, 359-373. [CrossRef]

105. Compeau, D.R.; Higgins, C.A. Computer Self-Efficacy: Development of a Measure and Initial Test. MIS Q. 1995, 19, 189. [CrossRef]

106. Igbaria, M. The effects of self-efficacy on computer usage. Omega 1995, 23, 587-605. [CrossRef]

107. Burkhardt, M.E.; Brass, D.J. Changing Patterns or Patterns of Change: The Effects of a Change in Technology on Social Network Structure and Power. Adm. Sci. Q. 1990, 35, 104. [CrossRef]

108. Gist, M.E.; Schwoerer, C.; Rosen, B. Effects of alternative training methods on self-efficacy and performance in computer software training. J. Appl. Psychol. 1989, 74, 884-891. [CrossRef]

109. Hill, T.; Smith, N.D.; Mann, M.F. Role of efficacy expectations in predicting the decision to use advanced technologies: The case of computers. J. Appl. Psychol. 1987, 72, 307-313. [CrossRef]

110. Lee, C. The Determinants of Innovation in the Malaysian Manufacturing Sector: An Econometric Analysis at the Firm Level. ASEAN Econ. Bull. 2004, 21, 319-329. [CrossRef]

111. Thatcher, J.B.; Perrewé, P.L. An Empirical Examination of Individual Traits as Antecedents to Computer Anxiety and Computer Self-Efficacy. MIS Q. 2002, 26, 381. [CrossRef]

112. Gilbert, S.; Loi, H. Digital Currency Risk. Int. J. Econ. Financ. 2018, 10, 108. [CrossRef]

113. Swan, M. Blockchain: Blueprint for a New Economy; O’Reilly Media, Inc.: Sebastopol, CA, USA, 2015.

114. Barratt, M.J. Silk Road: Ebay for Drugs. Addiction 2012, 107, 683. [CrossRef]

115. Trautman, L.J. Virtual Currencies; Bitcoin \& What Now after Liberty Reserve, Silk Road, and Mt. Gox? Richmond J. Law Technol. 2014, 20, 1-108.

116. Brito, J.; Castillo, A. Bitcoin: A Primer for Policymakers; Mercatus Center at George Mason University: Arlington, VA, USA, 2013.

117. Nakamoto, S. Bitcoin: A Peer-to-Peer Electronic Cash System. White Paper. 2008. Available online: http://bitcoin.org/bitcoin.pdf (accessed on 30 August 2019).

118. Clarke, R. Person location and person tracking-Technologies, risks and policy implications. Inf. Technol. People 2001, 14, 206-231. [CrossRef]

119. Obe, O.O.; Balogun, V.F. Practice, trends and challenges of mobile commerce in Nigeria. Inf. Technol. J. 2007, $6,448-456$.

120. Xu, G.; Gutierrez, J.A. An Exploratory Study of Killer Applications and Critical Success Factors in M-Commerce. J. Electron. Commer. Organ. 2006, 4, 63-79. [CrossRef]

121. Nooteboom, B. Diffusion, uncertainty and firm size. Int. J. Res. Mark. 1989, 6, 109-128. [CrossRef]

122. Classen, N.; Van Gils, A.; Bammens, Y.; Carree, M. Accessing Resources from Innovation Partners: The Search Breadth of Family SMEs. J. Small Bus. Manag. 2012, 50, 191-215. [CrossRef]

123. Wolf, E.J.; Harrington, K.M.; Clark, S.L.; Miller, M.W. Sample Size Requirements for Structural Equation Models: An Evaluation of Power, Bias, and Solution Propriety. Educ. Psychol. Meas. 2013, 76, 913-934. [CrossRef]

124. Taylor, S.; Todd, P.A. Understanding Information Technology Usage: A Test of Competing Models. Inf. Syst. Res. 1995, 6, 144-176. [CrossRef]

125. Bhattacherjee, A. Acceptance of e-commerce services: The case of electronic brokerages. IEEE Trans. Syst. Man Cybern. Part. A Syst. Hum. 2000, 30, 411-420. [CrossRef]

126. Shih, Y.; Fang, K. The use of a decomposed theory of planned behavior to study Internet banking in Taiwan. Internet Res. 2004, 14, 213-223. [CrossRef]

127. Davis, F.D.; Bagozzi, R.P.; Warshaw, P.R. Extrinsic and Intrinsic Motivation to Use Computers in the Workplace1. J. Appl. Soc. Psychol. 1992, 22, 1111-1132. [CrossRef]

128. Lu, Y.; Yang, S.; Chau, P.Y.; Cao, Y. Dynamics between the trust transfer process and intention to use mobile payment services: A cross-environment perspective. Inf. Manag. 2011, 48, 393-403. [CrossRef] 
129. Featherman, M.S.; Pavlou, P.A. Predicting e-services adoption: A perceived risk facets perspective. Int. J. Human-Comput. Stud. 2003, 59, 451-474. [CrossRef]

130. Hooper, D.; Coughlan, J.; Mullen, M. Structural Equation Modelling: Guidelines for Determining Model Fit. Electron. J. Bus. Res. Methods 2008, 6, 53-60.

131. Hayes, A.F. Introduction to Mediation, Moderation, and Conditional Process. Analysis: A Regression-Based Approach; The Guilford Press: New York, NY, USA, 2017.

132. Fornell, C.; Larcker, D.F. Evaluating structural equation models with unobservable variables and measurement error. J. Mark. Res. 1981, 18, 39-50. [CrossRef]

133. Baumgartner, H.; Homburg, C. Applications of structural equation modeling in marketing and consumer research: A review. Int. J. Res. Mark. 1996, 13, 139-161. [CrossRef]

134. Van De Vrande, V.; Lemmens, C.; Vanhaverbeke, W. Choosing governance modes for external technology sourcing. RD Manag. 2006, 36, 347-363. [CrossRef]

135. Campbell, D.T.; Fiske, D.W. Convergent and discriminant validation by the multitrait-multimethod matrix. Psychol. Bull. 1959, 56, 81-105. [CrossRef]

136. Hair, J.F.; Sarstedt, M.; Ringle, C.M.; Mena, J.A. An assessment of the use of partial least squares structural equation modeling in marketing research. J. Acad. Mark. Sci. 2012, 40, 414-433. [CrossRef]

137. Podsakoff, P.M.; MacKenzie, S.B.; Lee, J.-Y.; Podsakoff, N.P. Common method biases in behavioral research: A critical review of the literature and recommended remedies. J. Appl. Psychol. 2003, 88, 879-903. [CrossRef]

138. Fuller, C.M.; Simmering, M.J.; Atinc, G.; Atinc, Y.; Babin, B.J. Common methods variance detection in business research. J. Bus. Res. 2016, 69, 3192-3198. [CrossRef]

139. Triandis, H.C. The self and social behavior in differing cultural contexts. Psychol. Rev. 1989, 96, 506-520. [CrossRef]

140. Hofstede, G. Motivation, leadership, and organization: Do American theories apply abroad? Organ. Dyn. 1980, 9, 42-63. [CrossRef]

141. Karahanna, M.S. The Role of Espoused National Cultural Values in Technology Acceptance. MIS Q. 2006, 30, 679.

142. Anselin, L.J. Exploring spatial data with GeoDaTM: A workbook. 2005. Center for Spatially Integrated Social Science. Available online: http://csiss.org/clearinghouse/GeoDa/geodaworkbook.pdf (accessed on 6 March 2005).

(C) 2020 by the authors. Licensee MDPI, Basel, Switzerland. This article is an open access article distributed under the terms and conditions of the Creative Commons Attribution (CC BY) license (http://creativecommons.org/licenses/by/4.0/). 